Original Research

\title{
Family Counselling Enhances Environmental Control of Allergic Patients
}

\author{
Santi Dwi Lestari, Lailatun Nikmah, Ninuk Dian Kurniawati
}

Faculty of Nursing, Universitas Airlangga, Surabaya, Indonesia

\section{ABSTRACT}

Introduction: Allergies can cause complications such as inadequate nutrition, impaired sleep quality, and inhibition of child growth and development. There were about 15\% children who suffered from dust allergies in 2017 in Indonesia. Parents lacking of knowledge about environmental control can increase the prevalence of allergic relapse in children. Counselling is a method of health education that aims to improve knowledge, and practice. The purpose of this study was to investigate whether counselling has any influence on allergic related knowledge and environmental control measures skills.

Methods: The design of study was a pre-experiment design. There were 14 respondents in this study who were recruited at a university hospital based on inclusion criteria with consecutive sampling. The independent variable was counselling, the dependent variable were knowledge and environmental control measures. Data were collected using both a questionnaire was developed from the AAAAI and a check list was used to determine parents' skills on environmental controls. Data were analysed using Wilcoxon Sign Rank Test with significance level of $\alpha<0,05$.

Results: There was an influence of counselling on knowledge and environmental control measures (knowledge level, $\mathrm{p}=0,001$; practice level $\mathrm{p}=0,001$ ).

Conclusion: It is concluded that counselling is significantly increased knowledge and environmental control measures level.
\end{abstract}

\section{ARTICLE HISTORY}

Received: Dec 26, 2019

Accepted: Dec 31, 2019

\section{KEYWORDS}

allergy; house dust mites; environmental control; counselling; knowledge; practice

\section{CONTACT}

Ninuk Dwi Kurniawati

$\triangle$ ninuk.dk@fkp.unair.ac.id

$\equiv$ Faculty of Nursing, Universitas

Airlangga, Surabaya, Indonesia

Cite this as: Lestari, S.D., Nikmah, L., Kurniawati, N.D. (2019). Family Counselling Enhances Environmental Control of Allergic Patients. Jurnal Ners, Special Issues, 351-356. doi:http://dx.doi.org/10.20473/jn.v14i3.18069

\section{INTRODUCTION}

Despite its importance, the parents' knowledge and skills regarding house dust mites-environmentalcontrol are still lacking (Callahan et al., 2003). Globally, a review concluded that awareness of this type of allergy remains low (Calderón et al., 2015). If left untreated, the environment full of house dust mites will cause allergy and asthma attack to sensitive individual (Hauptman, Peden, \& Phipatanakul, 2018; Leas et al., 2018; Wilson \& Platts-Mills, 2018). Knowledge of parents with children allergic to house dust mites in the Allergy Outpatient Room at the Airlangga University Hospital regarding environmental control to reduce the house dust mite population is still inadequate. A survey conducted on March 5, 2018. showed that there were 3 out of 3 parents $(100 \%)$ who were unable to provide the right answer when they were given questions about how to wash linen to reduce the population of house dust mites; and 2 out of 3 parents (66\%) have not been able to provide appropriate answers on how to clean the environment to reduce the population of house dust mites. Existing studies on environmental controls that have been carried out shows that the knowledge of parents with house dust mite allergic children on environmental control is still low, even in 2003 after being given health education only $50 \%$ of parents had good knowledge regarding environmental control.

Allergy is a hypersensitivity reaction due to induction by IgE that is specific to certain allergens, which binds to mast cells. Allergens are ingredients that are generally harmless and are found in many environments but can cause allergic reactions if in contact with allergic patients (Ghosh et al., 2018; Leas 
et al., 2018; van Boven, Arends, Braunstahl, \& Gerth van Wijk, 2019; Wilson \& Platts-Mills, 2018; Wistiani \& Notoatmojo, 2011). In sort, allergies to house dust mites are a hypersensitivity reaction to house dust mite allergens.

Dust and dust mites are the most common allergens in the room and most often cause allergies (Burge \& Rogers, 2000; Cipriani, Calamelli, \& Ricci, 2017; Fujita, Matsui, \& Ito, 2015; Leas et al., 2018; Reisacher, 2011; Rogers, 2003; Syarifah, 2016; Wilson \& Platts-Mills, 2018; Wistiani \& Notoatmojo, 2011). House dust mites are the most common allergens found in rooms such as in the carpets and beds (Calderón et al., 2015; Thomas, 2015, 2018). House dust mites are animals of the araknoidea class (Leas et al., 2018; Rofieq, 2012). Stools and debris from house dust mites can cause allergy (Judarwanto, 2016; Svendsen, Gonzales, \& Commodore, 2018). Home dust mite allergies can be reduced by environmental controls (Reisacher, 2011; Sativa, 2017) however, parents' knowledge of environmental control is considered to be lacking.

The prevalence of allergies in the world has continued to increase for more than 50 years. The results of sensitization tests for one or more common allergens in 2016 among school children are close to $40 \%-50 \%$ worldwide. In $2012,10.6 \%$ or 7.8 million children reported respiratory allergies (Quamila, 2017). The number of children with allergies in Indonesia is estimated at 15\% (Judarwanto, 2016). The results of research by the University of Indonesia showed an increase in the percentage of children under 12 years of age with allergies to pollution and dust up to four times in the last 20 years, from $2 \%$ in 1980 and reaching 8\% in 2000 (Sánchez-Borges et al., 2017). Knowledge of parents who met the good category amounted to only $50 \%$ after being given health education in West Virginia in 2003.

Large number of accessible information about environmental controls to reduce the population of house dust mites, such as mass media, seminars and other health education does not necessarily improve parents' knowledge of environmental control. Lack of knowledge of parents about environmental control can increase the prevalence of allergic events in children. Allergies can cause other complications such as inadequate nutrition, disruption of the quality of sleep, inhibition of growth and development of children (Lorensia, Sari, Klinis-komunitas, \& Apoteker, 2017).

Counselling accompanied with leaflet as media on how to properly control the environment can be given to parents who have kids suffering allergy to house dust mites to enhance the parents' knowledge regarding allergic environmental control. Counselling are chosen because it is not only improving knowledge, but also provide ample time for parents with individual consultation; thus, it can help resolve individual obstacles in controlling the environment. Counselling is expected to be able to play a role in the process of behaviour change, namely awareness, interest, evaluation, trial and adoption of the behaviour; therefore, the parents' knowledge, attitude, skills and environmental control measures of house dust mites will increase, resulting in the suppression of the prevalence of allergies. The purpose of this study was to investigate whether counselling has any influence on allergic related knowledge and environmental control measures skills.

\section{MATERIALS AND METHODS}

The research design used was pre-experiment with one-group pre-post-test design. The process of data collection was carried out in July, 2018 at an Outpatient Clinic of Allergy of a university hospital in East Java. The independent variable in this study was counselling regarding environmental control given to parents or children. The dependent variable in this study is the knowledge and actions of parents or children in environmental control to reduce the population of house dust mites.

The population of this study were parents and children with children allergic to house dust mites who were treated at Outpatient Clinic of Allergy Universitas Airlangga Hospital Surabaya in July 2018. Respondents of 14 people were obtained using consecutive sampling with inclusion criteria: 1) parents with children who were suffering allergies to house dust mites, 2) parents or children with children who were seeking treatment at Outpatient Clinic of Allergy Universitas Airlangga Hospital Surabaya 3) parents or children with at least elementary education 4) parents or children who underwent immunotherapy programs every 1 week and 3 weeks

Data collection techniques were carried out using a knowledge questionnaire developed from Continuing Medical Education questions examinations sourced from The American Academy of Allergy, Asthma \& Immunology (AAAAI) (Tamsuri, 2008) and a check list instrument to determine parents' actions towards environmental controls to reduce house dust mite populations. right. Data analysis used the SPSS 16.0 for Windows program and tested the Wilcoxon Signed Rank Test statistically, namely p 5 0.05. This research has passed the ethical review from the health research 
ethics commission at the Airlangga University Hospital in Surabaya and received the research protocol approval with number 160 / KEH / 2018.

\section{RESULTS}

Based on Table 2. the majority of respondents had never received other information regarding environmental control before counselling as many as 9 people (64\%). A total of 4 respondents received information about environmental control more than 3 months ago or $28.5 \%$ of the total respondents. All respondents who had received information about environmental control came from other health education or $36 \%$ of the total respondents, and 1 respondent who accessed information about environmental control through the internet in addition to getting other health education or $7 \%$ of the total respondents.

Table 3. shows the Wilcoxon Signed Rank Test results. Wilcoxon Signed Rank Test is used to test for differences in pre-test and post-test results. The pretest results revealed that the knowledge level of most of the 8 respondents scored less (57\%) before being given counselling. An increase in the level of knowledge after being given counselling was 12 respondents (86\%) had a good level of knowledge. The Wilcoxon Signed Rank Test results obtained $\mathrm{p}=$ 0.001 so that $p<0.05$. This shows that there are differences between the results of the pre-test and post-test. It can be concluded that there is an effect of counselling on the knowledge of environmental control of parents with children allergic to house dust mites.

Based on Table 3, it is known that most of the 7 respondents $(50 \%)$ were in category of poor in skills of house-dust-mites-allergy environmental control before being given counselling. The level of skills had increased after counselling, which was 9 respondents (64\%) in the good category. The Wilcoxon Signed Rank Test between pre and post intervention was $\mathrm{p}=$

Table 1. Respondents' characteristics of Family counselling improves environmental control of house-dust-mites.

\begin{tabular}{|c|c|c|c|}
\hline \multicolumn{2}{|c|}{ Characteristics of respondents } & $\mathrm{n}$ & $\%$ \\
\hline \multirow{3}{*}{$\begin{array}{l}\text { Respondents' age (year } \\
\text { old) }\end{array}$} & $20-29$ & 4 & 28.5 \\
\hline & $30-39$ & 7 & 50 \\
\hline & $>40$ & 3 & 21.5 \\
\hline \multirow{5}{*}{ Kid's age (year old) } & $<1$ & 1 & 7 \\
\hline & $1-3$ & 4 & 28.5 \\
\hline & $3-5$ & 5 & 36 \\
\hline & $5-6$ & 1 & 7 \\
\hline & $6-18$ & 3 & 21.5 \\
\hline \multirow{4}{*}{ Education } & Basic Education (grades 1-6) & 1 & 7 \\
\hline & Basic Education (grades 7-9) & 1 & 7 \\
\hline & Secondary Education (grades 10-12) & 8 & 57 \\
\hline & Higher education & 4 & 29 \\
\hline
\end{tabular}

Table 2. Information regarding environmental control of house-dust-mites allergy.

\begin{tabular}{cccc}
\hline \multicolumn{2}{c}{ Category } & $\mathrm{n}$ & $\%$ \\
\hline Have received information & Yes & 5 & 36 \\
& No & 9 & 64 \\
\hline When was the last information & $<3$ & 1 & 7 \\
received (in month) & $>3$ & 4 & 28.5 \\
\hline Source of information & Other health education sources & 5 & 36 \\
& The internet & 1 & 7 \\
\hline
\end{tabular}

Table 3. Parents' knowledge and skills regarding the environmental control of house-dust mites-allergy at pre and post intervention.

\begin{tabular}{|c|c|c|c|c|c|c|c|c|}
\hline \multirow{3}{*}{ Level } & \multicolumn{4}{|c|}{ Knowledge } & \multicolumn{4}{|c|}{ Skills } \\
\hline & \multicolumn{2}{|c|}{ Pre } & \multicolumn{2}{|c|}{ Post } & \multicolumn{2}{|c|}{ Pre } & \multicolumn{2}{|c|}{ Post } \\
\hline & $\mathrm{n}$ & $\%$ & $\mathrm{n}$ & $\%$ & $\mathrm{n}$ & $\%$ & $\mathrm{n}$ & $\%$ \\
\hline Good & 1 & 7 & 12 & 86 & 1 & 7 & 9 & 64 \\
\hline Average & 5 & 36 & 1 & 7 & 6 & 43 & 5 & 36 \\
\hline Poor & 8 & 57 & 1 & 7 & 7 & 50 & 0 & 0 \\
\hline Mean & 4.79 & & 8.64 & & 2 & & 3.64 & \\
\hline Standar Deviation & 2.007 & & 1.393 & & 1.359 & & 0.497 & \\
\hline p (Wilcoxon signed rank test) & & 0.001 & & & & 0.001 & & \\
\hline
\end{tabular}


0.001 , suggesting that there were differences between the results of the pre-test and post-test. It can be concluded that there was an effect of counselling on environmental control measures of parents with children allergic to house dust mites.

\section{DISCUSSION}

Parents' knowledge of after counselling has increased compared to before counselling. Before being given counselling the level of knowledge of the majority of respondents was in the less category while only one respondent was in the good category. After counselling, post-test results show that counselling can facilitate an increase in the level of knowledge of parents towards environmental controls for allergic children to be better. This is indicated by the majority of respondents in the good category, one respondent in the sufficient category and one respondent in the less category.

Research conducted by Lorensia shows that education is effective in increasing knowledge (Soekidjo Notoatmojo, 2007). Health education controls the environment with counselling methods is the right method for parents with allergic children, because counselling can provide assistance to respondents to develop knowledge, and behaviour (Soekidjo Notoatmojo, 2003).

This is consistent with the an existing knowledge developed by Lawrence Green which divides factors that influence health behaviour into three, namely predisposing factors, supporting factors, and driving factors (L. W. Green, 1984). Predisposing factors consist of knowledge, attitude, age, and education (Soekidjo Notoatmojo, 2003, 2007). Supporting factors consist of health service personnel and information (L. W. Green, 1984). The driving factor consists of family support, health workers, and community leaders. The existence of supporting factors in this case information can increase one's knowledge (L. W. Green, 1984).

The level of knowledge is also influenced by the learning process (Soekidjo Notoatmojo, 2007). The learning process is influenced by the conditions of the subject of learning, among others, capture power, intelligence, memory, motivation and so on. Rogers (Soekidjo Notoatmojo, 2005) argues that before accepting an object of learning a sequential process occurs: awareness (the subject is aware of the learning object), interest (the subject feels attracted to the object), evaluation (the subject evaluates the bad or bad object), trial (the subject starts trying to do something in accordance with the object or stimulus), adaption (the subject behaves new in accordance with the knowledge, awareness and attitudes obtained) 21).

Notoatmodjo argues, one of the factors that influence knowledge is education (Soekidjo Notoatmojo, 2003). Knowledge is closely related to education (Soekidjo Notoatmojo, 2005). It is expected that the higher the level of education of a person, the higher the knowledge he has. Besides education, there are many factors that can affect one's knowledge, including age and experience. The thinking ability will be more mature as the person is getting older. Personal experience can also be used as a source of knowledge (Tamsuri, 2008).

Some respondents who have sufficient level of knowledge and one respondent who has a good level of knowledge before being given counselling can occur because respondents have previously obtained information on environmental control from other sources, namely health education received by respondents when children are allergic test respondents and respondents actively seek information through the internet.

The demographic data of respondents showed that the majority of respondents were in the category of 30-39 years so that most respondents were still classified as productive age who were still able to digest various information so that respondents could still be active and continue to learn so that the level of knowledge they possessed became better. Table 1.4 shows a change in knowledge from $57 \%$ of respondents in the category of knowledge level less than $86 \%$ of respondents are in the category of good knowledge level. In accordance with the theory of Notoatmodjo, the provision of information can facilitate the learning process of individuals to gain a new knowledge (Skinner, 1963).

Counselling can be the best choice in providing health education because counselling implements two-way communication between clients and counsellors so that perceptual inequality can be reduced. Another advantage of counselling is the content of counselling based on the problems faced by the client so that the health problems experienced by the client can be solved. However, giving counselling cannot change the knowledge of all respondents. There is one respondent who has not experienced an increase in knowledge; this may be due to several factors including: the age of the respondents who are older than other respondents, and the lack of concentration of respondents during the counselling process takes place.

Knowledge or cognitive is a very important domain in shaping one's actions (covert behaviour) (Soekidjo Notoatmojo, 2007). The process of 
changing respondents' knowledge through counselling will result in changes in house-dust-mite environmental control measures for allergy prevention.

The parents' skills after counselling have increased compared to before counselling. Before being given counselling the majority of respondents' level of skills were in the poor category while only one respondent was in the good category. After counselling, the post-test results showed that counselling can facilitate an increase in the level of parents' skill for environmental control for allergic children. This is shown in Table 1.5 that the majority of respondents became showed good skills in environmental control and some showed sufficient skills.

This finding shows that the health education of environmental control with counselling method is the right method for parents with allergic children, because counselling can provide assistance to respondents to develop knowledge, and behaviour (Soekidjo Notoatmojo, 2007). Skinner argues that behaviour is a certain order in terms of feelings (affections), thoughts (cognitions), and predisposing actions (conation) of someone to an aspect in the environment (Soekidjo Notoatmojo, 2003).

Action is the realization of a person's knowledge and attitudes in a real act (Tamsuri, 2008). Changes in actions can occur through processes or stages of change, namely knowledge, attitudes, and actions, which means that someone will only be able to perform well if the person already has a good knowledge and followed by a positive attitude. Nevertheless, some study found the different phenomenon: person can perform well even though they have poor knowledge and attitudes they have are still negative (Rogers, 2003). Anas (L. Green, 1991) states that the actions of an individual can arise not necessarily based on knowledge and attitude. While Rogers (Soekidjo Notoatmojo, 2007) argue the sustainability of a skill or performance unsupported with a good knowledge; if a behaviour is not based on knowledge and awareness then the behaviour will not last long.

Comparison of respondent's actions before and after counselling can be seen in Table 1.5 before giving counselling the majority of respondents included in the category of poor skill and action in term of controlling the environment, while only one respondent in the category of good action level. The majority of respondent had not been able to choose the right linen and to choose the right temperature for environmental control. At post interventions, the level of action of the majority of respondents increased to a good category, and some were in average category. These findings can best explained with the Precede-Procede-Lawrence Green-theory which assert that the provision of health education can change predisposing factors, supporting factors, and driving factors. The current study targeting the predisposing factors to change the respondents' knowledge; knowledge acquisition was considered as the important factors formed new skills and actions of environmental control. The process of forming actions goes through stages, such as perceptions, guided responses, mechanisms, and adoption (Soekidjo Notoatmojo, 2007).

Counselling can be the best choice in providing health education because counselling implements two-way communication between clients and counsellors so that perceptual inequality can be reduced. Another advantage of counselling is the content of counselling based on the problems faced by the client so that the health problems experienced by the client can be solved.

Some respondents still cannot the right temperature of water used to clean the house for environmental control; this may be due to several factors, among others: lack of enthusiasm of respondents, lack of concentration of respondents and research rooms that use air conditioner so that it can cause respondent's body temperature to cool down.

\section{CONCLUSION}

An increase in the level of knowledge of parents regarding environmental control after counselling. Moreover, there was an increase in the level of parental action regarding environmental control after counselling.

The results of this study are expected to be the initial data for the next researcher in analyzing and examining parents' knowledge of environmental control. The next researcher is expected to be able to examine the attitude variables that have not been studied in this study, test the validity of the questionnaire used and choose another place for research data collection other than in poly, or can do door to door for research data collection.

\section{REFERENCES}

Burge, H. A., \& Rogers, C. A. (2000). Outdoor allergens. Environmental Health Perspectives, 108(SUPPL. 4), 653-659.

Calderón, M. A., Linneberg, A., Kleine-Tebbe, J., De Blay, F., Hernandez Fernandez De Rojas, D., Virchow, J. C., \& Demoly, P. (2015). Respiratory allergy caused by house dust mites: What do we really know? Journal of Allergy and Clinical Immunology, 136(1), 38-48. 
https://doi.org/10.1016/j.jaci.2014.10.012

Callahan, K. ., Eggleston, P. ., Rand, C. ., Kanchanaraksa, S., Swarts, L. ., \& Wood, R. . (2003). Knowledge and practice of dust mite control by specialty care. Annals of Allergy, ASthma, And Immunology, 90(3), 302-307.

Cipriani, F., Calamelli, E., \& Ricci, G. (2017). Allergen Avoidance in Allergic Asthma. Frontiers in Pediatrics, https://doi.org/10.3389/fped.2017.00103

Fujita, M., Matsui, T., \& Ito, A. (2015). Biomedical insights into cell adhesion and migration-from a viewpoint of central nervous system tumor immunology. Front Cell Dev Biol, 3(October), 55. https://doi.org/10.3389/fcell.2015.00055

Ghosh, A., Dutta, S., Podder, S., Mondal, P., Laha, A., Saha, N. C., ... Saha, G. K. (2018). Sensitivity to House Dust Mites Allergens with Atopic Asthma and Its Relationship with CD14 C(-159T) Polymorphism in Patients of West Bengal, India. Journal of Medical Entomology, 55(1), 14-19. https://doi.org/10.1093/jme/tjx178

Green, L. (1991). Health Promotion Planning, An Educational and Environmental Approach (Mayfield P). California.

Green, L. W. (1984). Modifying and Developing Health Behavior. Annual Review of Public Health, 5, 215-236.

Hauptman, M., Peden, D., \& Phipatanakul, W. (2018). Environmental Control: The First Tenet of Allergy. Journal of Allergy and Clinical Immunology: In Practice, 6(1), 36-37. https://doi.org/10.1016/j.jaip.2017.10.022

Judarwanto, W. (2016). Alergi Makanan: Intoleransi Makanan.

Leas, B. F., D’Anci, K. E., Apter, A. J., Bryant-Stephens, T., Lynch, M. P., Kaczmarek, J. L., \& Umscheid, C. A. (2018). Effectiveness of indoor allergen reduction in asthma management: A systematic review. Journal of Allergy and Clinical Immunology, 141(5), 1854-1869. https://doi.org/10.1016/j.jaci.2018.02.001

Lorensia, A., Sari, N. P., Klinis-komunitas, D. F., \& Apoteker, P. S. (2017). Efektivitas edukasi untuk meningkatkan pengetahuan masyarakat dalam penanganan rinitis alergi. 3(2), 122-132.

Quamila, A. (2017). 3 Alergi Paling Umum di Indonesia. Reisacher, W. R. (2011). Allergy Treatment: Environmental Control Strategies. Otolaryngologic Clinics of North America, 44(3), 711-725. https://doi.org/10.1016/j.otc.2011.03.019

Rofieq, A. (2012). A Model of Allergen Inhalant Reduction Level on House Dust Based on Domestic Environment Management and Characteric. Proceeding Biology Education Conference, 633-641. Surakarta.

Rogers, C. A. (2003). Indoor Fungal Exposure. Immunology and Allergy Clinics of North
America, 23, 501-518.

Sánchez-Borges, M., Fernandez-Caldas, E., Thomas, W. R., Chapman, M. D., Lee, B. W., Caraballo, L., ... Capriles-Hulett, A. (2017). International consensus (ICON) on: Clinical consequences of mite hypersensitivity, a global problem. World Allergy Organization Journal, 10(1), 1-26. https://doi.org/10.1186/s40413-017-0145-4

Sativa, R. L. (2017). Di Indonesia, Dua Hal Ini yang Paling Sering Picu Alergi Anak.

Skinner, B. F. (1963). Operant Behaviour. Americant Psychologist, 18(8), 503-515. https://doi.org/http://dx.doi.org/10.1037/h0 045185

Soekidjo Notoatmojo. (2003). Pendidikan dan Perilaku Kesehatan. Jakarta: Rineka Cipta.

Soekidjo Notoatmojo. (2005). Metodologi Penelitian Kesehatan (2nd ed.). Rineka Cipta.

Soekidjo Notoatmojo. (2007). Promosi Kesehatan dan Ilmu Perilaku. Jakarta: Rineka Cipta.

Svendsen, E. R., Gonzales, M., \& Commodore, A. (2018). The role of the indoor environment: Residential determinants of allergy, asthma and pulmonary function in children from a USMexico border community. Science of the Total Environment, 616-617, 1513-1523. https://doi.org/10.1016/j.scitotenv.2017.10.1 62

Syarifah, F. (2016, October). Waspadai 7 Penyebab Alergi Paling Umum. Liputan 6.Com.

Tamsuri, A. (2008). Konseling dalam Keperawatan. Jakarta: EGC.

Thomas, W. R. (2015). Hierarchy and molecular properties of house dust mite allergens. Allergology International, 64(4), 304-311. https://doi.org/10.1016/j.alit.2015.05.004

Thomas, W. R. (2018). IgE and T-cell responses to house dust mite allergen components. Molecular Immunology, 100(November 2017), 120-125.

https://doi.org/10.1016/j.molimm.2018.03.01 6

van Boven, F. E., Arends, L. R., Braunstahl, G. J., \& Gerth van Wijk, R. (2019). A re-introduction of environmental mite allergen control strategies for asthma treatment and the debate on their effectiveness. Clinical \& Experimental Allergy, (September 2018), 1-10. https://doi.org/10.1111/cea.13340

Wilson, J. M., \& Platts-Mills, T. A. E. (2018). Home Environmental Interventions for House Dust Mite. Journal of Allergy and Clinical Immunology: In Practice, 6(1), 1-7. https://doi.org/10.1016/j.jaip.2017.10.003

Wistiani, \& Notoatmojo, H. (2011). Hubungan Pajanan Alergen Terhadap Kejadian Alergi pada Anak. SariPediatri, 13(3), 185-190. 